\title{
Monitoring of Chlamydia trachomatis infections after antibiotic treatment using RNA detection by nucleic acid sequence based amplification
}

\author{
S A Morré, P T G Sillekens, M V Jacobs, S de Blok, J M Ossewaarde, P van Aarle, \\ $B$ van Gemen, J M M Walboomers, C J L M Meijer, A J C van den Brule
}

Department of Pathology, Section of Molecular Pathology, University Hospital Vrije Universiteit, De Boelelaan 1117, 1081 HV Amsterdam, The Netherlands

S A Morré

M V Jacobs

J M M Walboomers

C J L M Meijer

A J C van den Brule

Organon Teknika BV, Business Area Nucleic Acid Diagnostics, Boseind 15, 5281 RM

Boxtel, The

Netherlands

P T G Sillekens

$P$ van Aarle

$B$ van Gemen

Department of Obstetrics and Gynaecology, OLVG Hospital, 1

Oosterparkstraat 179, 1091 HA Amsterdam, The Netherlands $S$ de Blok

Research Laboratory for Infectious Diseases, National Institute of Public Health and the Environment, PO Box 1, 3720 BA, Bilthoven, The Netherlands

J M Ossewaarde

Correspondence to: Dr van den Brule. email: vandenbrule@azvu.nl

Accepted for publication 11 March 1998

\begin{abstract}
Aim-To investigate the value of RNA detection by nucleic acid sequence based amplification (NASBA) for the monitoring of Chlamydia trachomatis infections after antibiotic treatment.

Methods-Cervical smears $(n=97)$ and urine specimens $(n=61)$ from $25 C$ trachomatis positive female patients were analysed for the presence of $C$ trachomatis $16 S$ ribosomal RNA (rRNA) by NASBA and $C$ trachomatis plasmid DNA by the polymerase chain reaction (PCR) before and up to five weeks after antibiotic treatment.
\end{abstract}

Results-Chlamydia trachomatis RNA was found in all cervical smears taken before antibiotic treatment $(n=24)$ and in two smears taken one week after antibiotic treatment; no $C$ trachomatis RNA was detected after two weeks or more. In contrast, $C$ trachomatis DNA was found in all such specimens before treatment, and 21 of 25, six of 21, and five of 20 smears were found to be positive at one, two, and three weeks after treatment, respectively. After four weeks, only one of six smears was positive, and this smear had been negative in the two preceding weeks. Of the 61 urine samples investigated, $C$ trachomatis DNA and $C$ trachomatis RNA were found in all before treatment $(n=15)$, whereas one week after treatment four of 15 were $C$ trachomatis DNA positive and $C$ trachomatis RNA was detected in one sample only.

Conclusions-These data show that RNA detection by NASBA can be used successfully to monitor $C$ trachomatis infections after antibiotic treatment. Furthermore, it might be possible to use urine specimens as a test of cure because neither $C$ trachomatis DNA or RNA could be detected two weeks or more after treatment. (f Clin Pathol: Mol Pathol 1998;51:149-154)

Keywords: Chlamydia trachomatis; nucleic acid sequence based amplification; antibiotic treatment

Chlamydia trachomatis, an obligate intracellular microorganism, is the most prevalent sexually transmitted agent in the USA and western Europe. ${ }^{12}$ The urogenital diseases, caused mainly by $C$ trachomatis serovars $\mathrm{D}-\mathrm{K}$, include urethritis, endometritis, cervicitis, and pelvic inflammatory disease. In addition, asymptomatic infections could, when untreated, result in ectopic pregnancy and tubal infertility. ${ }^{3}$ In general, treatment of these infections with antibiotics (such as doxycycline and azitromycin) is effective. ${ }^{45}$ However, in some cases, recurrent $C$ trachomatis infections have been seen after antibiotic treatment. ${ }^{46}$ This could be a result of reinfection or it may represent persistent disease. Although these persistent cases have been described in vitro, ${ }^{78}$ no direct evidence of $C$ trachomatis persistence in humans has been reported to date.

To monitor the efficiency of antibiotic treatment of $C$ trachomatis, both cell culture and DNA amplification techniques (the polymerase chain reaction (PCR) and the ligase chain reaction (LCR)) have been used. After antibiotic treatment, $C$ trachomatis DNA is still found for up to three weeks, ${ }^{9}{ }^{10}$ although cell culture results are negative one week after antibiotic treatment. ${ }^{569-11}$ This might result from the detection of DNA from non-viable $C$ trachomatis organisms by PCR after antibiotic treatment. Therefore, detection of viable microorganisms after such treatment by cell culture is clinically more relevant than DNA detection by the PCR. However, cell culture can be rather insensitive compared with PCR because of the high demands on sampling of the clinical material and subsequent transport to the laboratory to retain viability of the microorganisms. Alternatively, detection of RNA sequences also measures biological activity and might be an indicator of gene expression and cell viability. Recently, the sensitive isothermal RNA amplification method, that is, NASBA has made its appearence and has been used successfully for the detection of $C$ trachomatis in cervical smears and urine specimens. ${ }^{12}$ With this technique and using L2 serovar dilution lines, it was possible to detect 0.001 inclusion forming units (IFU) $v 0.01 \mathrm{IFU}$ with PCR. ${ }^{12}$ Recently, $C$ trachomatis detection in urine, a non-invasive sampling method, has been introduced successfully for the routine diagnosis of $C$ trachomatis infections. The detection of $C$ trachomatis DNA in urine by $\mathrm{PCR}^{13}$ and $\mathrm{LCR}^{15} 16$ is highly sensitive and specific compared with cell culture and enzyme immunoassay (EIA). This suggests that urine could possibly be used for the detection of either $C$ trachomatis DNA by PCR or $C$ trachomatis RNA by NASBA for the monitoring of $C$ trachomatis, instead of using cell culture of cervical smears.

In our study, we investigated the value of RNA detection by NASBA for the monitoring 
of $C$ trachomatis infections after antibiotic treatment. Therefore, both cervical smears and urine specimens from $C$ trachomatis positive women were analysed for the presence of both $C$ trachomatis DNA by PCR and $C$ trachomatis RNA by NASBA before and up to five weeks after antibiotic treatment. Furthermore, NASBA using such specimens was evaluated for its use as a test of cure.

\section{Materials and methods}

SPECIMEN COLLECTION

Cervical smears $(n=97)$ were obtained from 25 symptomatic patients attending the department of Gynaecology, OLVG Hospital in Amsterdam for a variety of gynaecological complaints. In addition, urine samples $(\mathrm{n}=61)$ were obtained from 16 patients. These patients, who were found to be positive for $C$ trachomatis by EIA (Chlamydiazyme; Abbott Diagnostic Division, Amstelveen, The Netherlands), were treated with 100 mg doxycycline twice a day for one week and were monitored for five weeks. Cervical smears were collected before antibiotic treatment $(t=0$; $\mathrm{n}=24$, one cervical smear was not obtained) and one week $(\mathrm{t}=1 ; \mathrm{n}=25)$, two weeks $(\mathrm{t}=2$; $\mathrm{n}=21)$, three weeks $(\mathrm{t}=3 ; \mathrm{n}=20)$, four weeks $(\mathrm{t}=4 ; \mathrm{n}=6)$, and five weeks $(\mathrm{t}=5$; $\mathrm{n}=1$ ) after the start of treatment. In addition, $15,15,13,13$, four, and one urine specimens, respectively, were collected at these time points. Cervical smears were collected with cervical brushes (Rover BV, Oss, The Netherlands) and placed in $3 \mathrm{ml}$ of lysis buffer (50 mM Tris/ $\mathrm{HCl}$ pH 6.4, $20 \mathrm{mM}$ EDTA, $1.3 \% \mathrm{wt} / \mathrm{vol}$ Triton $\mathrm{X}-100,5.25 \mathrm{M}$ guanidinium thiocyanate (GuSCN)). After vortexing, the samples were transported to the laboratory at room temperature on the day of collection. The cervical brushes were removed after vortexing and the samples were diluted further with $7 \mathrm{ml}$ lysis buffer and stored at $-80^{\circ} \mathrm{C}$.

First void urine samples were collected into sterile containers (content $25 \mathrm{ml}$ ), transported at room temperature, and processed immediately by centrifuging $1.5 \mathrm{ml}$ at $16000 \times g$ (Merck, Eppendorf Centrifuge 5415C; Merck, Amsterdam, The Netherlands) for 10 minutes. Supernatants were discarded and pellets stored at $-80^{\circ} \mathrm{C}$.

PRETREATMENT OF CLINICAL SPECIMENS FOR NASBA/PCR

Nucleic acid (DNA/RNA) released in the lysed cervical cell suspension was bound to activated silica $(70 \mu \mathrm{l}$ of silica, $1 \mathrm{~g} / \mathrm{ml}$ suspension in $0.1 \mathrm{~N} \mathrm{HCl}$; Fluka Chemie AG, Buchs, Switzerland) during 10 minutes of incubation at room temperature. ${ }^{17}$ After washing and drying of the silica, the nucleic acid was eluted in $75 \mu \mathrm{l}$ of distilled water. For DNA/RNA purification from urine, $1 \mathrm{ml}$ of lysis buffer was added to the $1.5 \mathrm{ml}$ urine pellets. Subsequently, the silica based nucleic acid isolation method was performed as described for the cervical smears.

DETECTION BY PCR

Each specimen was subjected to human $\beta$ globin PCR to check the suitability of the processed sample for PCR purposes, as described previously. ${ }^{3}$ Plasmid specific primers (PL6.1: 5'-AGAGTACATCGGTCAACGA-3' and PL6.2: 5'-TCACAGCGGTTGCTCGAAGCA-3'; synthesised by Perkin Elmer, Nieuwerkerk a/d Amstel, The Netherlands) ${ }^{12}$ were used for PCR amplification. As a positive control, a 10 fold dilution series of $C$ trachomatis L2 nucleic acid was used as described previously. ${ }^{12}$

These PCRs were performed as described previously $^{918}$ in a total volume of $50 \mu \mathrm{l}$, containing $50 \mathrm{mM} \mathrm{KCl}, 1.5 \mathrm{mM} \mathrm{MgCl}_{2}$, $0.2 \mathrm{mM}$ of each dNTP, $25 \mathrm{pmol}$ of each primer, $1 \mathrm{U}$ of Taq polymerase (Amplitaq; Cetus, Emeryville, California, USA), and $5 \mu \mathrm{l}$ of isolated nucleic acid. Amplification by the PCR consisted of denaturation for four minutes at $94^{\circ} \mathrm{C}$, followed by 40 cycles of amplification: each cycle consisted of one minute at $95^{\circ} \mathrm{C}$, one minute at $55^{\circ} \mathrm{C}$, and 1.5 minutes at $72^{\circ} \mathrm{C}$. The final elongation step was extended for another four minutes. The amplified DNA was analysed by $1.5 \%$ agarose gel electrophoresis and ethidium bromide staining. Additional Southern blot analysis was performed by transfer of the DNA on to positively charged nylon membranes (Qiabrane nylon plus; Qiagen $\mathrm{GmbH}$, Hilden, Germany) with diffusion blotting in $0.5 \mathrm{~N} \mathrm{NaOH}, 0.6 \mathrm{M} \mathrm{NaCl}$. Membranes were preincubated for two hours at $55^{\circ} \mathrm{C}$ in hybridisation solution $(0.5 \mathrm{M}$ sodium phosphate, $\mathrm{pH} 7.4,7 \%$ sodium dodecyl sulphate (SDS), $1 \mathrm{mM}$ EDTA). Afterwards, a specific ${ }^{32} \mathrm{P}$-dATP end labelled oligonucleotide probe (OT1570: 5'CGTGCGGGGTTATCTTAAAAGGGAT-3') was added and hybridisation was carried out at the same temperature overnight. Subsequently, the membranes were washed three times using $3 \times$ SSC $/ 0.5 \%$ SDS ( $1 \times$ SSC: $0.15 \mathrm{M} \mathrm{NaCl}$, $0.015 \mathrm{M}$ sodium citrate) for 30 minutes at $55^{\circ} \mathrm{C}$. Autoradiography was performed at $-80^{\circ} \mathrm{C}$ with Kodak Royal X-Omat films and intensifying screens.

DETECTION BY NASBA

Primers specific for $C$ trachomatis $16 \mathrm{~S}$ rRNA (OT1257: 5'-AATTCTAATACGACTCAC TATAGGGCTCGGATGCCCAAATATCGC CACA-3' = T7-primer and OT1252: 5'GATGAGGCATGCAAGTCGGAA-3') were synthesised and purified as described previously. ${ }^{19}$ To exclude either the presence of inhibitory factors in the amplification or inefficient sample preparation an internal standard, which is not amplified by NASBA in the presence of wild-type $C$ trachomatis $16 \mathrm{~S}$ ribosomal RNA (rRNA), was added to cervical smears and urine specimens before sample preparation as described previously. ${ }^{12}$ From a wild-type 16S rRNA stock ${ }^{12}$ a 10 fold dilution series was made from $2 \times 10^{3}$ to $2 \times 10^{-1}$ molecules/ $\mu \mathrm{l}$, from which $5 \mu \mathrm{l}$ was used for NASBA, generating positive controls from $10^{4}$ to $10^{\circ}$ target molecules in the final NASBA reaction mixtures. NASBA amplifications were carried out as described by Kievits et al with minor modifications. ${ }^{19}$ Reactions were performed in a $20 \mu \mathrm{l}$ reaction mixture containing $40 \mathrm{mM}$ Tris 


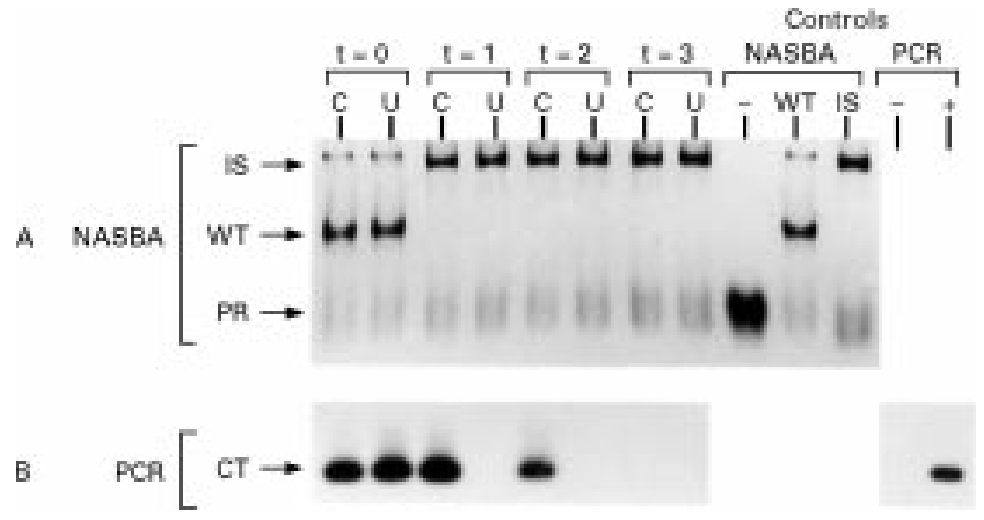

Figure 1 Detection of Chlamydia trachomatis in cervical smears and corresponding urine specimens. (A) Chlamydia trachomatis and NASBA products detected by ELGA before antibiotic treatment $(t=0)$ and 1,2 , and 3 weeks after treatment. (In the WT C trachomatis NASBA positive samples, an amplimer of unknown origin, which is slightly longer than the IS, was observed as described previously). ${ }^{12}$ (B) Corresponding $C$ trachomatis PCR products detected by Southern blot hybridisation. C, cervical smear; ELGA, enzyme linked gel assay; IS, 16S rRNA NASBA internal standard (285 nucleotides); PR: probe; U, urine; WT, wild-type $16 S \mathrm{rRNA}$ (151 nucleotides).

pH 8.5 (Sigma, Poole, Dorset, UK), $12 \mathrm{mM}$ $\mathrm{MgCl}_{2}$ (Sigma), $70 \mathrm{mM} \mathrm{KCl}$ (Mallinckrodt Baker B.V., Deventer, The Netherlands), $5 \mathrm{mM}$ dithiothreitol (DTT; Sigma), 15\% vol/vol dimethyl sulphoxide (DMSO; Sigma), $1 \mathrm{mM}$ of each deoxy-nucleotide triphosphate (dNTP; Pharmacia Biotech Benelux, Roosendaal, The Netherlands), $2 \mathrm{mM} \mathrm{rATP/rUTP/}$ rCTP and $1.5 \mathrm{mM}$ rGTP (Pharmacia), $0.5 \mathrm{mM}$ ITP (Boehringer, Mannheim, Germany), $2.1 \mu \mathrm{g}$ bovine serum albumin (BSA; Boehringer), $0.08 \mathrm{U}$ RNaseH (Pharmacia), $6.4 \mathrm{U}$ avian myeloblastosis reverse transcriptase (AMV-RT; Seikagaku America Inc, Ijamsville, Maryland, USA), 32 U T7 RNA polymerase (Pharmacia), $0.2 \mu \mathrm{M}$ of each primer, and $5 \mu$ of isolated nucleic acid. Reactions were performed at $41^{\circ} \mathrm{C}$ for 90 minutes and were stopped by placing the reaction mixtures on ice. The amplified product was detected by means of an enzyme linked gel assay (ELGA). ${ }^{20}$ Precautions similar to those for PCR were taken to prevent contamination.

For detection by ELGA, $3 \mu \mathrm{l}$ of RNA from NASBA, $1 \mu \mathrm{l}$ of $6 \times$ SSC, $1 \mu \mathrm{l}$ of layermix, and $1 \mu \mathrm{l}$ of target specific horseradish peroxidase (HRP) probe (5'-NH ${ }_{2}$ AGCAATTGTTT CGGCAATTGTTT-3') at $3.3 \times 10^{-8} \mathrm{M}$ were incubated for 15 minutes at $45^{\circ} \mathrm{C}$. An aliquot of $3 \mu \mathrm{l}$ of this solution was used for electrophoresis on a $7 \%$ polyacrylamide/ bisacrylamide gel containing $0.04 \%$ dextran sulphate. The gel was stained on a rotation shaker, using a tetra methyl benzidine (TMB) substrate solution $(0.5 \mathrm{ml}$ of TMB/DMSO $(5 \mathrm{mg} / \mathrm{ml}), 24.5 \mathrm{ml}$ of TMB buffer $(10 \mathrm{mM}$ citrate, $10 \mathrm{mM}$ EDTA, $\mathrm{pH} 4.8$, and $2.5 \mu \mathrm{l}$ of $\left.\mathrm{H}_{2} \mathrm{O}_{2}\right)$ ), until the blue bands became clearly visible.

\section{CELL CULTURE}

To compare PCR and NASBA results with those of cell culture, five additional culture positive cervical smears were included. After removing cervical mucous, one swab (cotton tipped with aluminium shaft; Hospidex, Nieuwkoop, The Netherlands) was taken for isolation of $C$ trachomatis in cell culture. The swab was placed in $2 \mathrm{ml}$ chlamydia transport medium 4SP (0.4 M sucrose phosphate buffer, $\mathrm{pH} 7.2$, supplemented with $10 \%$ fetal calf serum and antibiotics) and stored at $-80^{\circ} \mathrm{C}$ until cultured. Cell culture was performed according to routine procedures. Briefly, HeLa 229 cells (ATCC CCL 2.1) were maintained in Iscove's modified Dulbecco's medium (Gibco Life Sciences, Breda, The Netherlands) supplemented with $10 \%$ fetal calf serum and antibiotics. One day old monolayers of HeLa 229 cells were used for the isolation of $C$ trachomatis. All monolayers were pretreated with $30 \mu \mathrm{l} / \mathrm{ml}$ DEAE dextran in Hank's balanced salt solution for 15 minutes at room temperature. Clinical specimens were thawed rapidly in a water bath at $37^{\circ} \mathrm{C}$ and vortexed vigorously. Then, $0.3 \mathrm{ml}$ was inoculated on to a monolayer on a glass cover slip in a shell vial. The vials were centrifuged for one hour at $4800 \times g$ at $25^{\circ} \mathrm{C}$ and incubated at $37^{\circ} \mathrm{C}$ with $5 \% \mathrm{CO}_{2}$ for three days. Chlamydia trachomatis growth was assessed by staining with fluorescein labelled monoclonal antibodies (PathoDx assay; Diagnostic Products Corporation, Los Angeles, USA). For PCR and NASBA assays, $0.5 \mathrm{ml}$ aliquots of the 4SP samples were centrifuged at $16000 \times g$ for 30 minutes. Subsequently, the pellet was resuspended in lysis buffer (L6) and nucleic acid was isolated with the silica based isolation method already described.

The sensitivity of cell culture was compared with NASBA and PCR using serial dilutions. Five clinical isolates were cultured as described above until $25-50 \%$ was infected with $C$ trachomatis. Isolates were resuspended in $2 \mathrm{ml}$ Iscove's modified Dulbecco's medium and sonicated. Serial dilutions of $300 \mu$ l were made from $10^{-3}$ to $10^{-10}$. Subsequently, $100 \mu 1$ was used for cell culture and $100 \mu \mathrm{l}$ was used to isolate the nucleic acid obtained in a $200 \mu \mathrm{l}$ eluate. The remaining $100 \mu \mathrm{l}$ was stored at $-80^{\circ} \mathrm{C}$ as a backup. Cell culture results were evaluated after two days using the PathoDx assay (Diagnostic Products Corporation). NASBA and PCR were performed using $5 \mu \mathrm{l}$ nucleic acid as described above.

\section{Results}

DETECTION OF C TRACHOMATIS RNA AND DNA IN CERVICAL SMEARS

A comparison of RNA detection using NASBA and DNA detection using PCR was made on cervical smears $(\mathrm{n}=97)$ of $C$ trachomatis EIA positive patients $(n=25)$ followed up for four weeks after antibiotic treatment. All cervical smears tested were positive for $\beta$ globin PCR, indicating that no inhibition of DNA amplification occurred.

Figure 1 shows the results of $C$ trachomatis specific RNA and DNA detection in cervical smears from a representative patient before and up to three weeks after antibiotic treatment. Before antibiotic treatment, both $C$ trachomatis RNA as detected by $16 \mathrm{~S}$ rRNA NASBA and visualised by ELGA (151 nucleotides; fig 1A) and $C$ trachomatis DNA as detected by plasmid PCR (130 base pairs; fig 1B) are present. After antibiotic treatment, $C$ trachomatis RNA is no longer detected, whereas the NASBA internal 

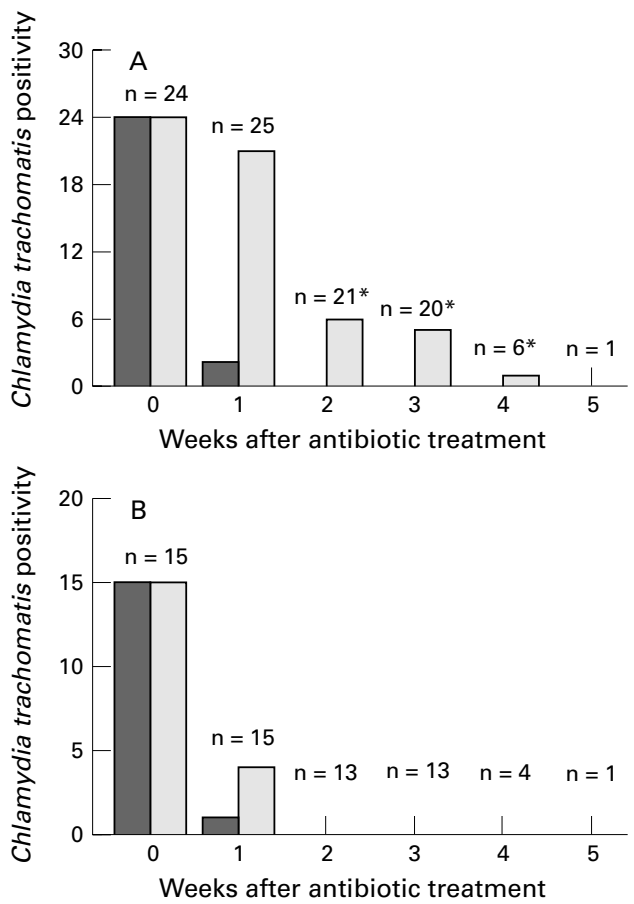

Figure 2 (A) The number of Chlamydia trachomatis positive samples in cervical smears and (B) urine specimens before and after antibiotic treatment. Chlamydia trachomatis infections were analysed by plasmid DNA PCR (ight grey bars) and $16 S$ rRNA NASBA (dark grey bars). This figure also contains the four cases showing fluctuating $C$ trachomatis DNA PCR results, which are described in detail in table $1 .{ }^{*}$, contains sample (s) in which the preceding smear was $C$ trachomatis DNA negative.

standard (285 nucleotides) is clearly visible. This was the case in all cervical smears negative for chlamydia, which indicates that there was no inhibition of amplification and that sample preparation was adequate. Chlamydia trachomatis DNA was still detectable up to two weeks after antibiotic treatment, as shown by Southern blot hybridisation (fig 1B).

Results of the $C$ trachomatis DNA and RNA detection in all of the cervical smears tested are summarised in fig 2A. Before antibiotic treatment $(\mathrm{t}=0) C$ trachomatis $\mathrm{RNA}$ and DNA could be detected in all cervical smears $(\mathrm{n}=24)$. One week after the start of antibiotic treatment $(\mathrm{t}=1), C$ trachomatis $\mathrm{RNA}$ was present in only two of 25 cervical smears, although $C$ trachomatis DNA could still be detected in 21 of 25 such specimens. From two weeks after treatment $(\mathrm{t}=2), C$ trachomatis RNA was no longer detected (fig 2A). In contrast, at week $2(\mathrm{t}=2)$, week $3(\mathrm{t}=3)$, week 4 $(\mathrm{t}=4)$, and week $5(\mathrm{t}=5) C$ trachomatis $\mathrm{DNA}$ was present in six of 21 , five of 20 , one of six, and none of one cervical smears, respectively (fig 2A). In four of these patients, reappearance of $C$ trachomatis DNA was seen in their smears even though the preceding smear had been negative (table 1). However, these cases were only weakly positive after Southern hybridisation and no $C$ trachomatis RNA could be detected by NASBA.

DETECTION OF C TRACHOMATIS RNA AND DNA IN URINE SPECIMENS

Comparison of RNA detection using NASBA and DNA detection using PCR of $C$ trachomatis was also performed on first void urines $(\mathrm{n}=61)$ from 16 patients with $C$ trachomatis EIA positive cervical smears. All urine specimens tested were positive for $\beta$ globin PCR, indicating that no inhibition of DNA amplification had occurred.

Results of $C$ trachomatis RNA and DNA detection in urine specimens from a representative patient before and up to three weeks after antibiotic treatment are shown in fig 1, along with the results of the corresponding cervical smears. Before treatment, both $C$ trachomatis RNA as detected by $16 \mathrm{~S}$ rRNA NASBA (151 nucleotides; fig 1A) and $C$ trachomatis DNA as detected by plasmid PCR (130 bp; fig 1B) were present. After antibiotic treatment, $C$ trachomatis RNA or DNA were not detected (fig $1 \mathrm{~A}$ and $\mathrm{B}$ ), whereas the NASBA internal standard (285 nucleotides) was clearly visible.

The results of $C$ trachomatis DNA and RNA detection in all the urine specimens tested are summarised in fig $2 \mathrm{~B}$. Before antibiotic treatment, $C$ trachomatis RNA and DNA could be detected in all urine specimens $(n=15)$. One week after antibiotic treatment, $C$ trachomatis RNA was seen in only one of 15 urine specimens, although $C$ trachomatis DNA was still detected in four of 15 specimens. This included one urine specimen that initially showed no amplification by NASBA, but a new nucleic acid isolation of the same urine specimen showed amplification of the $16 \mathrm{~S}$ rRNA internal standard, indicating inefficient isolation the first time. At weeks 2, 3, 4, and 5 neither $C$ trachomatis RNA nor DNA could be detected.

COMPARISON OF CELL CULTURE AND $C$ TRACHOMATIS RNA AND DNA DETECTION USING CERVICAL SMEARS

The comparison between cell culture, RNA detection using NASBA, and DNA detection using PCR was performed on cervical smears $(\mathrm{n}=19)$ of $C$ trachomatis cell culture positive

Table 1 NASBA and PCR results from patients with reappearing Chlamydia trachomatis DNA

\begin{tabular}{|c|c|c|c|c|c|c|c|c|c|c|c|c|}
\hline \multirow[b]{2}{*}{ Patient } & \multicolumn{2}{|l|}{$t(0)$} & \multicolumn{2}{|l|}{$t(1)$} & \multicolumn{2}{|l|}{$t(2)$} & \multicolumn{2}{|l|}{$t(3)$} & \multicolumn{2}{|l|}{$t(4)$} & \multicolumn{2}{|l|}{$t(5)$} \\
\hline & $\begin{array}{l}C x \\
N, P\end{array}$ & $\begin{array}{l}U r \\
N, P\end{array}$ & $\begin{array}{l}C x \\
N, P\end{array}$ & $\begin{array}{l}U r \\
N, P\end{array}$ & $\begin{array}{l}C x \\
N, P\end{array}$ & $\begin{array}{l}U r \\
N, P\end{array}$ & $\begin{array}{l}C x \\
N, P\end{array}$ & $\begin{array}{l}U r \\
N, P\end{array}$ & $\begin{array}{l}C x \\
N, P\end{array}$ & $\begin{array}{l}U r \\
N, P\end{array}$ & $\begin{array}{l}C x \\
N, P\end{array}$ & $\begin{array}{l}U r \\
N, P\end{array}$ \\
\hline 1 &,++ &,++ &,-+ &,-- &,-- &,-- &,-- &,-- &,-+ &,-- &,-- &,-- \\
\hline 2 &,++ & NA &,-+ & NA &,-- & NA &,-+ & NA & NA & NA & NA & NA \\
\hline 3 &,++ & NA &,-- & NA &,-+ & NA &,-- & NA & NA & NA & NA & NA \\
\hline 4 &,++ & NA &,-- & NA &,-- & NA &,-+ & NA & NA & NA & NA & NA \\
\hline
\end{tabular}

$\mathrm{t}(0)$, before treatment; $\mathrm{t}(1), \mathrm{t}(2), \mathrm{t}(3), \mathrm{t}(4)$, and $\mathrm{t}(5): 1,2,3,4$, and 5 weeks after antibiotic treatment, respectively. $\mathrm{Cx}$, cervical smear; Ur, first void urine specimen; P, Chlamydia trachomatis plasmid PCR followed by Southern blot hybridisation; $\mathrm{N}, 16 \mathrm{~S}$ rRNA NASBA followed by enzyme linked gel assay (ELGA); NA, specimen not available. 
patients $(n=5)$ followed up for four weeks after antibiotic treatment. All cervical smears tested were positive for $\beta$ globin PCR and the NASBA internal standard was clearly visible in all $C$ trachomatis RNA negative cervical smears, indicating that no inhibition of amplification had occurred.

Before antibiotic treatment, cell culture was positive for all patients. Also, both $C$ trachomatis RNA as detected by $16 \mathrm{~S}$ rRNA NASBA and $C$ trachomatis DNA as detected by plasmid PCR were present. One week after the start of the antibiotic treatment all cervical smears were negative by cell culture for $C$ trachomatis. On the other hand, $C$ trachomatis RNA was detected in one cervical smear, and $C$ trachomatis DNA was detected in all five such specimens one week after the start of the antibiotic treatment. Two, three, and four weeks after antibiotic treatment (no specimens were obtained at weeks 2 and 3 from three patients) neither $C$ trachomatis DNA nor RNA was detected.

To compare the sensitivity of cell culture with NASBA and PCR in a reconstruction experiment, serial dilutions of five clinical isolates were made and subsequently subjected to cell culture, PCR, and NASBA analysis. The following dilutions could be detected by cell culture, PCR, and NASBA, respectivelyseries $1: 10^{-6}, 10^{-6}, 10^{-7}$; series $2: 10^{-5}, 10^{-6}$, $10^{-7}$; series 3: $10^{-6}, 10^{-6}, 10^{-7}$; series $4: 10^{-5}$, $10^{-6}, 10^{-7}$; and series $5: 10^{-5}, 10^{-5}, 10^{-6}$.

\section{Discussion}

Our study shows the value of RNA detection by NASBA for the monitoring of $C$ trachomatis infections after antibiotic treatment. One week after the start of such treatment, $C$ trachomatis RNA could be detected in only two cervical smears, and after two weeks of treatment, no $C$ trachomatis RNA was detectable (fig $2 \mathrm{~A}$ ). Also, in those cases with cell culture proven $C$ trachomatis infections, only one case showed $C$ trachomatis RNA one week after antibiotic treatment, while cell cultures were negative up to four weeks after treatment. These cell culture results are in complete agreement with those obtained in other studies. ${ }^{56-11}$ Some groups ${ }^{46}$ reported culture positive results after antibiotic treatment. However, these data appeared to be derived from patients with a history of continued unprotected sexual intercourse with an untreated $C$ trachomatis infected partner.

In contrast to $C$ trachomatis RNA, $C$ trachomatis DNA could be detected in many of the cervical smears one week after antibiotic treatment (Fisher's exact test, $\mathrm{p}<0.00001$; two tailed, OR $=46$ (95\% CI, 9.8 to 216.1$)$ ). In all patients showing consistent $C$ trachomatis DNA results, $C$ trachomatis DNA disappeared from the cervical smears two to three weeks after antibiotic treatment (the four patients with reappearing $C$ trachomatis DNA will be discussed later). These results are in agreement with other studies, in which $C$ trachomatis DNA could also be detected up to two ${ }^{611}$ or three weeks $^{69}$ after antibiotic treatment using PCR. These data demonstrate that the presence of $C$ trachomatis DNA after antibiotic treatment reflects excretion of non-viable organisms because cell culture was negative in these studies. In all cases where no $C$ trachomatis RNA could be detected by NASBA, cell culture results were always negative, despite the presence of $C$ trachomatis DNA. Therefore, RNA detection by NASBA is likely to be more clinically relevant than testing for DNA by PCR after antibiotic treatment. Furthermore, RNA detection is not an absolute marker for $C$ trachomatis viability because $C$ trachomatis $\mathrm{RNA}$ was detected one week after treatment, whereas cell culture was negative. However, these few discrepancies between cell culture and NASBA results could also be explained by the relative insensitivity of cell culture in the detection of $C$ trachomatis infections in clinical specimens (such as inefficient culture because of low titre infections, effects of transport, or inhibition). Moreover, PCR and NASBA were $0-10$ and 10-100 times more sensitive, respectively, compared with cell culture using dilution series of clinical isolates. When taking into account the proportion of the original sample used for analysis (40 times more for cell culture) the higher sensitivity of the amplification assays compared with cell culture becomes even more evident.

The main advantages of RNA detection by NASBA, as compared with cell culture for the identification of viable microorganisms, include its high sensitivity and reliability resulting from the internal standard used. Furthermore, the results can be obtained within one working day. In addition to the monitoring of antibiotic treatment, RNA detection could also be a good alternative for studying the activity of new antibiotics in vitro and could be used to compare the activities of different antibiotics in vivo, using both cervical smears and urine specimens.

Before antibiotic treatment, the urine specimens of all patients were clearly positive for both $C$ trachomatis DNA and RNA (fig $2 \mathrm{~B}$ ). In such samples, a prominent decrease in $C$ trachomatis RNA $v$ DNA was found one week after antibiotic treatment (one of $15 v$ four of 15; $\mathrm{p}=0.3295$; two tailed, not significant (NS)), and no $C$ trachomatis DNA or RNA were found two weeks or more after treatment. In one urine specimen in which $C$ trachomatis RNA could be detected after antibiotic treatment, $C$ trachomatis DNA and RNA were also detected in the corresponding cervical smear. No difference in $C$ trachomatis RNA clearance was found between urine specimens and cervical smears ( $p=1.00001$; two tailed, NS). In contrast, in most cases with a $C$ trachomatis positive cervical smear one week after treatment, the corresponding urine specimen appeared to be $C$ trachomatis DNA negative $(\mathrm{p}=0.00206$; two tailed, OR $=11(95 \% \mathrm{CI}$, 2.3 to 52.6$)$ ). This difference in $C$ trachomatis DNA detection might be explained by the fact that residual $C$ trachomatis organisms present in the urinary tract were eradicated through frequent urination, whereas the cervical mucosa may have retained these residual organisms for a longer time. The difference in eradication time could also reflect a difference 
in antibiotic levels achieved in the cervix versus the urethra, because doxycycline is found in the urine at high concentrations. Two weeks after antibiotic treatment, $C$ trachomatis RNA was no longer detected in both cervical smears and urine specimens, and $C$ trachomatis DNA was not detected in urine specimens. This quick eradication of $C$ trachomatis DNA and RNA in the urinary tract makes urine potentially suitable for use as a test of cure using NASBA or PCR. The use of urine will facilitate sample collection greatly because of its noninvasiveness, in contrast to the use of cervical smears. As described in different studies using both PCR and LCR for the detection of $C$ trachomatis ${ }^{13-16}$ urine specimens could be used reliably instead of cervical smears.

Interestingly, the reappearance of $C$ trachomatis DNA in cervical smears after a 1-2 week $C$ trachomatis DNA free interval was seen in four cases (table 1). However, these cases were only weakly positive after Southern hybridisation. These fluctuating results might be caused by sampling differences in the specimens. Alternatively, the $C$ trachomatis DNA reappearance might reflect reinfection with $C$ trachomatis or reactivation upon withdrawal of antibiotics. However, this is unlikely because no $C$ trachomatis RNA could be detected in these specimens (the NASBA internal standard was visible, indicating that sample preparation was adequate and that inhibition of amplification had not occurred). Moreover, from two of these four patients with reappearing $C$ trachomatis DNA (patients 1 and 3, table 1), cervical smears were again negative for both $C$ trachomatis DNA and RNA one week later (weeks 5 and 4 , respectively). This suggests strongly that the $C$ trachomatis DNA reappearance was not related to reinfection or to reactivated chlamydia infection, but originated from residual non-viable material. Therefore, our study did not find any evidence for in vivo persistent $C$ trachomatis infections. In contrast, these persistent $C$ trachomatis infections have been described in vitro, characterised by the presence of enlarged, atypical chlamydia forms that are non-infectious but retain viability. Suppression by antibiotics, cytokines, and nutrient depletion are responsible for these persistent forms in cell culture. ${ }^{78}$

In conclusion, our study shows that RNA detection by NASBA can be used successfully for the monitoring of $C$ trachomatis infections after treatment with antibiotics. Furthermore, it might be possible to use urine specimens as a test of cure using either NASBA or PCR, because neither $C$ trachomatis DNA or RNA could be detected two weeks after antibiotic treatment.
This work was partly supported by grant $28-1182-1$ from the Prevention Fund, The Netherlands. The authors acknowledge $\mathrm{K}$ Schaub for the excellent coordination of the collection of clinical specimens.

1 Schryver de A., Meheus A. Epidemiology of sexually transmitted diseases: the global picture. Bull WHO 1990;68:639-54.

2 Centers for Disease Control. Chlamydia trachomatis infections: policy guidelines for prevention and control. Morb Mortal Wkly Rep 1995;34:53S-74S.

3 Lan J, van den Brule AJC, Hemrika DJ, et al. Chlamydia trachomatis and ectopic pregnancy: retrospective analysis of salpingectomy specimens, endometrial biopsies and cervical smears. F Clin Pathol 1995;48:815-19.

4 Hammerschlag MR, Golden NH, Kim Oh M, et al. Single dose of azithromycin for the treatment of genital chlamydial infections in adolescents. F Pediatr 1993;122:961-5.

5 Martin DH, Mroczkowski TF, Dalu ZA, et al. A controlled trial of a single dose of azithromycin for the treatment of chlamydial urethritis and cervicitis. $N$ Engl $\mathcal{F} \mathrm{Med}$ 1992;327:921-5.

6 Workowski KA, Lampe MF, Wong KG, et al. Long-term eradication of Chlamydia trachomatis genital infection after anti-microbial therapy. $\mathscr{f} A M A$ 1993;270:2071-5.

7 Beatty WL, Morrison RP, Byrne GI. Immunoelectronmicroscopic quantitation of differential levels of chlamydia proteins in a cell culture model of persistent Chlamydia trachomatis infection. Infect Immun 1994;62:4059-62.

8 Beatty WL, Belanger TA, Desai AA, et al. Tryptophan depletion as a mechanism of gamma interferon-mediated chlamydial persistence. Infect Immun 1994;62:3705-11.

9 Roosendaal R, Walboomers JMM, Veltman OR, et al. Comparison of different primer sets for detection of Chlamydia trachomatis by the polymerase chain reaction. $\mathcal{F} \mathrm{Med}$ Microbiol 1993;38:426-33.

10 Vogels WHM, van Voorst Vader PC, Schröder FP. Chlamydia trachomatis infection in a high-risk population: comparison of polymerase chain reaction and cell culture for diagnosis and follow-up. F Clin Microbiol 1993;31:11037 .

11 Goessens WHF, Kluytmans, JAJW, den Toom N, et al. Influence of volume of sample processed on detection of Chlamydia trachomatis in urogenital samples by PCR. $\mathcal{F}$ Clin Microbiol 1995;33:251-3.

12 Morré SA, Sillekens P, Jacobs MV, et al. RNA amplification by nucleic acid sequence-based amplification with an internal standard enables reliable detection of Chlamydia nal standard enables reliable detection of Chlamydia
trachomatis in cervical scrapings and urine samples. 7 Clin trachomatis in cervical scraping

13 Bianchi A, Scieux C, Brunat N, et al. An evaluation of the polymerase chain reaction amplicor Chlamydia trachomatis in male urine and female urogenital specimens. Sex Transm Dis 1994;12:196-200.

14 Jaschek G, Gaydos CA, Welsh LE, et al. Direct detection of Chlamydia trachomatis in urine specimens from symptomatic and asymptomatic men by using a rapid polymerase chain reaction assay. $\mathcal{F}$ Clin Microbiol 1993;31:1209-12.

15 Chernesky MA, Jang D, Lee H, et al. Diagnosis of Chlamydia trachomatis infections in men and women by testing first-void urine by ligase chain reaction. $f$ Clin Microbiol 1994;32:2682-5.

16 Gaydos CA, Ngeow YF, Lee HH, et al. Urine as a diagnostic specimen for the detection of Chlamydia trachomatis in Malaysia by ligase chain reaction. Sex Transm Dis 1996;23: 402-6.

17 Boom R, Sol CJA, Salimans MMM, et al. Rapid and simple method for purification of nucleic acids. $\mathcal{f}$ Clin Microbiol 1990;28:495-503.

18 Lan J, Walboomers JMM, Roosendaal R, et al. Direct detection and genotyping of Chlamydia trachomatis in cervical scrapes by using polymerase chain reaction and restriction fragment polymorphism analysis. F Clin Microbiol 1993;31: $1060-5$.

19 Kievits T, van Gemen B, van Strijp D, et al. NASBA ${ }^{\mathrm{TM}}$ isothermal enzymatic in vitro nucleic acid amplification optimized for the diagnosis of HIV-1 infection. F Virol Methods 1991;35:273-86.

20 van Gemen B, Kievits T, Nara P, et al. Qualitative and quantitative detection of HIV-1 RNA nucleic acid sequencebased amplification. Current Science AIDS 1993;7(suppl 2):S107-10 